International Journal of Arts and Humanities (IJAH)

Bahir Dar- Ethiopia

Vol. 4(2), S/No 14, April, 2015: 179-188

ISSN: 2225-8590 (Print) ISSN 2227-5452 (Online)

DOI: http://dx.doi.org/10.4314/ijah.v4i2.13

\title{
An Evaluation of Banks' Liability in Robbery Incidents at Banks' Premises in Nigeria
}

\author{
Garuba, Anthony O. \\ Department of Accounting and Finance \\ College of Social and Management Sciences \\ Western Delta University \\ Oghara, Delta State Nigeria \\ E-mail: anthonygaruba@yahoo.com \\ $\boldsymbol{\&}$ \\ Otomewo, Gene Oghenenohwo T. \\ Department of Management Sciences \\ College of Social and Management Sciences \\ Western Delta University \\ Oghara, Delta State Nigeria \\ E-mail: oghenenohwo@yahoo.com
}

\begin{abstract}
The spate of armed robbery attack on banks in the last decade has been alarming. It is hoped with the current Central Bank of Nigeria (CBN) cashless policy there will be a drastic drop in such incidents. However, the issue of armed robbery attack at the bank premises brings to the fore two issues which are of paramount interest to the banker,
\end{abstract}

Copyright (C IAARR 2014: www.afrrevjo.net/ijah

Indexed African Journals Online (AJOL) www.ajol.info 
customer and the general public. The issues are: (a) is the family of a bank customer killed by armed robbers in the banking hall during a transaction entitled to compensation? (b) Is a customer who is attacked by armed robbers in the banking hall and whose cash is snatched in the process of being lodged in; entitled to compensation from the bank? Therefore, the paper is aimed at examining banks' liability in robbery incidents. The study adopts a theoretical approach and use of secondary data. The findings show that it is not in all cases that the customer will be compensated. It depends on the merit of the case and the stage the title in cash passes to the bank. Based on the findings it is recommended that banks' should train their staff to be security conscious and how to behave in case of robbery attacks so as not to endanger their lives; and that of the customers.

Key words: Liability, robbery, customer, security, cash and premises.

\section{Introduction}

The crime rate in Nigeria has assumed an alarming proportion. There are many factors that could have given rise to the crime rate in Nigeria. Some researchers have linked the crime situation in Nigeria to purely economic factors. Akinrinde (2007) contends that no income coming in, and no savings to fall back on, many retrenched people are said to have found themselves in a struggle for survival. Many that cannot find alternative jobs, but must keep body and soul together decide to plunge into crime. Contemporary issues of post-consolidation and the recent bank crisis have made the banking industry worst hit in terms of job insecurity. Most banks' management always have the erroneous impression that the solution to their problem is by 'right sizing' or 'down-sizing'; which is not always true. They only succeed in increasing the army of experienced bankers that are being thrown into the already saturated unemployment market. Some of such ex-bankers are determined to make a living from the banking system even from outside, either by perpetuating fraud or giving out information to armed robbers. The heightened tension amongst banks' staff as a result of the job pressure and the insecurity pervading the banking industry constitute a great temptation for otherwise honest staff, to look for the nonexistent pension and gratuity by settling themselves if the opportunity presents itself.

Also Odekunle (2005) singles out relative poverty and unemployment as justification for criminal behaviour in Nigerian towns and cities. Banks have become the major target of robbery attacks in recent times notwithstanding the presence of armed policemen in the banks' premises. These dare devil robbers are motivated to embark on their nefarious act because banks trade on commodity (money) which everybody needs and the sophisticated arms at their disposal. Sad enough they carry out their dastardly act more often than not during the day. Unfortunately, some banks' customers in the process of transacting business in the banks have lost their lives due to armed robbery attack. The dependants and family of such a victim would want the

Copyright (C) IAARR 2014: www.afrrevjo.net/ijah

Indexed African Journals Online (AJOL) www.ajol.info 
banks to compensate them. Also customers', whose cash was snatched by armed robbers when being lodged in, would also want the banks to compensate them. However, for banks to be held liable for compensation depends on the merit of the case.

Therefore, the objective of this paper is to examine banks' liability in robbery incidents. The paper is structured into six (6) parts. The first part deals with the security at the banks premises while the second part discusses cash request and evacuation. The third part focuses on staff recruitment in the banking industry. The fourth part examines the compensation if any, due to the family of a bank customer killed by armed robbers in the banking hall during a transaction. While the fifth part explores at what stage a title in cash passes to the bank and the relevance of insurance. The sixth part concludes the discourse and proffers recommendations.

\section{Security at the Bank's Premises}

There is no doubt that banks owe their customers who come to the banking premises to transact business a duty to keep the premises reasonably safe from thieves and armed robbers. When customers or depositors get to the bank premises they expectedly relax their guard somewhat, knowing that the bank has security to keep the premises reasonably secured. According to Chianu (1995), if the bank fails to act prudently taking into account the crime history of the area, the bank is situate, it would be said that it has breached its duty. It is mandatory that before banks open their doors for business daily, they must ensure that the armed policemen posted to the banks to provide security report for duty. Appropriate records of the police posting and resumption are kept at both the police station and the banks. The policemen posted to the banks must sign for arms at the police station and when they report at the bank, they also sign the bank's security book whereby they enter the date, time in, time out, any incident, signature and remark. Banks also have their internal security to complement the police. In most cases they outsource the internal security services to reputable security companies.

Where a bank opens its door for business without providing armed policemen on duty and a robbery incident occurs, the bank will be held liable to pay compensation to the family of the victim killed or a customer whose cash is snatched. If it can be proven that the bank failed to provide adequate security, it cannot escape liability. Therefore, the onus is on the family of the victim or the customer to prove that the bank did not provide adequate security or was negligent in not providing security in its premises.

\section{Cash Request/Evacuation}

The Head of Cash and Teller plays an important role in the cash management of a bank's branch office because he co-ordinates the activities of the Tellers and

Copyright (C) IAARR 2014: www.afrrevjo.net/ijah

Indexed African Journals Online (AJOL) www.ajol.info 
Note Counters. He reports to the Branch Manager or Head of Operations and aids the branch in cash planning. He is in a position to know when the branch should request for cash or when to evacuate cash. In either evacuating or requesting for cash from the Bullion centre, the Head of Cash and Teller and the Branch Manager must ensure that such information does not get to the wrong hands or unauthorized persons for security reasons. Therefore, information relating to cash request/evacuation must be kept confidential because most of the robbery attacks on banks are traceable to such information. The ability of the banks to manage such confidential information helps to check or prevent robbery attacks. Where there are no robbery attacks the issue of liability will not arise.

\section{Staff Recruitment}

In the past before the era of the new generation banks in the 1990s, banks paid much attention to the character of staff before they are recruited. The banks ensured that the staff employed were of good character, honest and hardworking. According to Garuba and Aigbe (2010), it is rather unfortunate that these days banks employment is based on "who you are connected to" and "how much deposits can you mobilize?" while qualities such as honesty, good character and hard work are relegated to the background. It is some of these staff of questionable character who collude with fraudsters or armed robbers to attack the banks. They divulge confidential information to fraudsters and the armed robbers. Nwaze (2009) says that since it is an established fact that no bank fraud succeeds without the active support, collaboration or connivance of staff, it stands to reason that you should understand the kind of staff that are working for you. A good understanding of the private and official dispositions of the generality of staff in your branch or department, their career history and records as well as their individual nuances and idiosyncrasies will enable you gauge the risk you run by keeping each of them, and by extension, the operational risk you need to mitigate. It does not relate to fraud alone it also includes robbery incidents in the banking industry. Most crime and security experts believe that there is always insider information in any successful robbery incident in the banking industry. It is therefore, advisable that banks should screen the character of their staff before recruiting them. Where honest and dedicated staff are recruited, it would help to check the incessant robbery incidents and the banks will not be exposed to liability claims.

\section{Is the family of a bank customer killed by armed robbers in the banking hall during a transaction entitled to compensation?}

Unfortunately, most banks' customers in the course of transacting business at their banks have lost their lives in the banking hall during armed robbery attack. Garuba (2008) states that in most cases the lives of the "bread winners" of families are cut short by these dare devil robbers thereby inflicting untold hardship on their

Copyright (C) IAARR 2014: www.afrrevjo.net/ijah

Indexed African Journals Online (AJOL) www.ajol.info 
dependants. Therefore, families who lost their relatives under such circumstances would normally want the bank to pay them compensation in order to ameliorate the hardship of the dependants of the victims. But the big question is: Are they entitled to such compensation? Under the law, there is no compensation for families of bank customers killed during a raid on banks by armed robbers. Banks are not under any obligation to pay compensation to families of customers who died during raids on their premises. There is no occupied liability. Such a customer went to the bank to transact business and if, unfortunately, he loses his life in the process, the family is not entitled to compensation. However, where a bank decides to pay something to such victim's family, it will be purely on a sympathetic basis. This could be viewed as a corporate social responsibility by the bank and not a legal compensation. On the other hand, the circumstances leading to the death of the victim would determine whether compensation would be paid or not. For instance, if the family is able to prove that the bank failed to provide adequate security, then it can claim compensation from the bank. But where the bank took all necessary precautionary measures in providing security and yet the robbers struck, due to no negligence on its part, and killed a customer during the raid, it cannot be made liable to pay compensation to the family of the victim. This is because the law does not provide for occupied liability in bank premises.

\section{At what stage does a title in cash passes to the bank?}

There have been instances where robbers struck when customers were lodging cash in the banking hall. As for Garuba (2010), there is this erroneous impression that once a customer or his agent is in the banking hall to lodge in cash when robbers raid a bank, the customer must be compensated. It is not in all cases that the customer will be compensated. It depends on the merit of the case. If the teller (cashier) had received, counted and accepted the customer's cash before the armed robbers swooped on the customer, the bank will be liable but any cash of the customer not yet received and counted by the teller, the bank cannot be held liable to compensate the customer. The case decided and reproduced below gives a vivid account of at what stage the title in cash passes to the bank.

\section{Balmoral Supermarket Ltd V Bank of New Zealand (1974) 2 Lloyd's Rep 164}

The employee of the plaintiff went to the defendant bank to lodge in the sum of NZ\$4020.83, made up of $\$ 660.83$ in cheques and $\$ 3,360$ in cash. The employee had already placed the cash on the counter while the cashier took $\$ 100$ in one bundle, counted them and put them aside. Armed robbers swooped on the employee while the $\$ 3,260$ was still on the employee's side of the counter and made away with the cash. The plaintiff claimed for the return of $\$ 3,260$ from the bank on the ground that when the employee placed the cash on the counter in front of the cashier, with the intention that it should be banked the possession of the property in the money passed to the

Copyright $\odot$ IAARR 2014: www.afrrevjo.net/ijah

Indexed African Journals Online (AJOL) www.ajol.info 
defendants so that they were liable to account for it, even though it had been taken by the robbers. However, no negligence on the bank's part was alleged. The New Zealand Supreme court held that the property in the money had not passed to the bank, nor did they have legal possession of it. McMullin, J. "It is not alleged that there was any negligence on the part of defendant and in my view, the question of liability falls to be determined by reference to the relationship between defendant as banker and plaintiff as customer. It has long been decided that the relationship of banker and customer is that of debtor and creditor... It was pointed out by Lord Justice Bankes in Joachimson V Swiss Bank Corp (1921) 3 KB110 at P118 that the decision in Foley V Hill (1848) 2HL Cas. 28 cannot be treated as an exhaustive definition of all the obligations arising out of the relationship between banker and customer, the debtor and creditor relationship is still the basic principle of banking and it is of application here. Before such a relationship can be created and the bank made the debtor of the customer, circumstances must be shown to exist from which it can be established that the bank became debtor of the customer: that can only arise if there has first been a deposit. Without such a deposit or lodgment of moneys with the bank, the latter cannot be said to be the debtor of the customer liable to account for moneys upon demand being made in terms of the contract. In the present case, as a matter of fact, it cannot be said that the cash placed upon the counter for counting by the cashier had ever been received in such a way by the bank as to create a debtor and creditor relationship. All but $\$ 100$ of the money remained to be checked and in the ordinary course of business it would have been expected that the cash would first be checked by the cashier to ascertain whether the full sum was in fact there. There may have been shortage in the notes or some of them may have been defaced.

A bank should not have to account for money, which it has no opportunity to check upon. Only when such a check had been made and the banker had signified his acceptance of the sum intended to be banked could there be said to be a deposit of such funds with the banker so as to constitute the banker liable to repay to the customer the equivalent of the amount banked. Plaintiff's submission requires acceptance of the untenable proposition that a banker is liable to a customer for a sum of money from the moment that it has been placed in front of the banker with the intention that it be banked without first offering the opportunity to the banker to check on the amount for which he will be liable subsequently to account. If this were true then... a new dimension of liability would be placed on bankers. Counsel for plaintiff has [further] submitted that when the cash was placed in front of the teller for him to count, possession of such money, and therefore the property in it, passed to the banker. Generally, property in cash passes with possession because it is a primary characteristic of currency that it may pass from hand to hand without any question as to title. As Lord Haldane, L.C. said in Sinclair, V. Brougham (1914) AC 398 at 418:

Copyright () IAARR 2014: www.afrrevjo.net/ijah

Indexed African Journals Online (AJOL) www.ajol.info 
If a sovereign or bank note be offered in payment it is, under ordinary circumstances, no part of the duty of the person receiving it to enquire into title. The reason of this is that chattels of such a kind form part of what the law recognizes as currency, and treats as passing from hand to hand in point, not merely of possession, but of property. It would cause great inconvenience to commerce if in this class of chattel an exception were not made to the general requirement of the law as to title. In the present case I do not think that the property in the money ever passed because the bank cannot be said to have had legal possession against the plaintiff of the moneys placed upon the counter, although, even to the extent that this existed, I am of the opinion that it was a joint factual possession shared with plaintiff. Such possession as the bank had was in my view, not legal possession...

\section{Insurance}

Insurance policy is normally taken by banks to hedge its risk exposure in relation to cash. Such insurance include Cash on Premises (COP), cash in transit and fidelity. It should be noted that the said insurance is not to compensate the customer or family of a victim killed in the banking hall during robbery attack but for the bank's cash.

\section{Cash on Premises (COP)}

Banks take insurance policy to cover their cash on premises (COP). The banks pay premium to insurance companies for providing such cover. It is advisable that banks should operate within the approved limit of its COP. Where the COP limit is exceeded as a result of cash deposits, the excess must be reported by the branches to its Head Offices to enable them make adequate arrangement for excess cover. Where the branch fails to notify its Head office in order to provide cover for the excess, if any robbery incident occurs, the insurance company will not pay claims relating to the excess. It means the bank will bear the excess risk. Once there is excess, efforts must be made by the branch immediately to regularize the excess either by evacuation to its nearest bullion centre or utilized for payments. It is also important for the branch to notify its head office when the excess is regularized. COP is basically determined by the volume of cash transaction of a branch based on cash statistics over a given period of time.

\section{Cash in Transit}

Banks are also expected to take insurance policy for movement of cash and cash picks. In case of robbery during cash movement, the insurance company will

Copyright () IAARR 2014: www.afrrevjo.net/ijah

Indexed African Journals Online (AJOL) www.ajol.info 
IJAH 4(2), S/NO 14, APRIL, $2015 \mid 186$

indemnify the bank but where the bank fails to take insurance policy, it will bear its loss.

\section{Conclusion}

In this paper we tried as much as possible to bring to the fore what could constitute a liability to the bank in robbery incidents. We explored security at bank's premises, cash request/evacuation and how insurance cover could help to mitigate banks' risks. We do hope that if banks' management implements the recommendations proffered, it would go a long way in addressing the challenges of robbery attacks in the Nigerian banking industry.

\section{Recommendations}

The following recommendations are proffered to enable banks check robbery incidents, manage its liability and security:

(1) Banks should maintain good relationship with the police and ensure that policemen are at their premises to provide security before opening for the day's business. Also Police escort must be used for all cash movements.

(2) Banks should train their staff to be security conscious and how to behave in case of robbery attacks. This is necessary so that they will not endanger their lives and that of the customers during robbery incidents.

(3) Banks should install Closed Circuit Television (CCTV) to monitor activities in the premises. If placed in strategic positions in the bank, it could help to reveal the identity of the armed robbers and can be very useful in the course of investigation.

(4) Banks should have reinforced vault rooms, standard doors and chub cash safe to guard against easy break-in and fire outbreak.

(5) Alarm systems should be installed for security reasons. The system should be activated after the close of the day's transactions to guard against burglars intrusion, for it would trigger heavy alarm which might likely attract attention and possibly scare away the robbers. The system could also be activated in case of armed robbery attack. It is advisable that the banks should link their alarm system to the police station, to alert the police in cases of emergency.

(6) There should be proper vault cash management in branches. The importance of proper cash planning for the smooth running of a branch cannot be overemphasized. Excess cash should be promptly evacuated to guard against robbery attacks and idle cash, because idle cash does not earn any income.

Copyright (C) IAARR 2014: www.afrrevjo.net/ijah

Indexed African Journals Online (AJOL) www.ajol.info 
(7) For security reason, tellers are not expected to keep or hold too much cash at any point in time. The Head of Cash and Teller should ensure that excess cash is promptly reserved into the vault.

(8) Banks should review its recruitment process to ensure that staff recruited is of good character, honest and hard working.

(9) Government should, as matter of urgency, provide jobs to the army of unemployed youths. Most of the youths take to robbery because of lack of gainful employment.

(10) Security at our borders and ports should be beefed up by the government to check the illegal importation of arms and ammunition. The arms and ammunition in circulation is alarming hence most of the robbers have access to sophisticated weapons they use for their nefarious acts.

(11) Information relating to cash request and evacuation should be treated as top secret and should not be allowed to get to unauthorized persons. Such information should be treated with utmost confidentiality.

(12) Banks should have their internal security to complement the police and they should be well trained.

(13) Banks should ensure that they purchase and use armoured vehicles for their cash movements.

(14) The new CBN cashless policy should be supported by all stakeholders because if well implemented, it will help to address bank robberies and corruption in our society.

\section{References}

Akinrinde, S. (2007). Menace of bandits. Newswatch. Lagos: Newswatch Communications Ltd.

Chianu, E. (1995). Law of banking: Texts: Cases: Comments. Benin: Enslee Books.

Driscoll, M.C. (2006). Cash management-corporate strategies for profit. London: Wiley-Inter Science Publication.

Garuba, A.O. (2008). Fundamentals of banking, Vol.1. Benin: Ambik Press Ltd.

Garuba, A.O. (2010). Cash lodgement in the Nigerian banking industry. Benin Journal of Social Sciences. 18(1\&2), 7-18.

Copyright () IAARR 2014: www.afrrevjo.net/ijah

Indexed African Journals Online (AJOL) www.ajol.info 
IJAH 4(2), S/NO 14, APRIL, $2015 \mid 188$

Garuba, A. O. \& Aigbe, P. (2010). Automated teller machine (ATM) and its challenges in contemporary Nigerian banking industry. AAU Journal of Management Sciences. 1(1), 133-146.

Nwaze, C. (2009). Fraud and anti-fraud challenges in contemporary Nigerian banking. Zenith Economic Quarterly. 4(2), 32.

Odekunle, F.L. (2005). Crime and social defence: A social development in Nigeria. Ibadan: University Press Ltd.

Copyright $($ IAARR 2014: www.afrrevjo.net/ijah

Indexed African Journals Online (AJOL) www.ajol.info 